\title{
Quantitative strain analysis of strike-slip displacements across the Ame-Elin trend, the Danish Central Graben
}

\author{
OLE RØNØ CLAUSEN, JOHN A. KORSTGÅRD \& TOMMY M. EGEBJERG
}

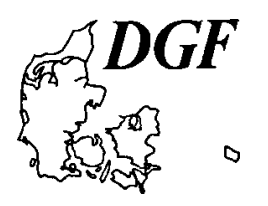

Clausen, O.R., Korstgård, J. A. \& Egebjerg, T. M.:Quantitative strain analysis of
strike-slip displacements across the Ame-Elin trend, the Danish Central Graben.
Bulletin of the Geological Society of Denmark, Vol. 43, pp. 99-113.
Copenhagen, 1996-12-05. https://doi.org/1-0.3757-0/bgsd-1996-43-11

A method is presented for unravelling the displacement history across transpressionand transtension zones recognized on seismic sections as flower structures. The method has been applied to the Ame-Elin trend in the northem part of the Danish Central Graben. The results suggest sinistral movement with alternating transpression and transtension along strike during the Early Cretaceous, and dextral transpressive movement during the Late Cretaceous and Paleogene. However, there is considerable variation in displacement along strike of the zone during the individual periods. The variation in displacement along the strike of the Ame-Elin trend is accommodated by displacement along the fault systems in the adjoining areas. The displacement along fault systems in the adjoining areas was sinistral during the Early Cretaceous and dextral during the post-Early Cretaceous, similar to the movement along the Ame-Elin trend during the two periods.

The analysis gives a detailed picture of the movements along the general structural trend and emphasizes the differences between the two periods. One of the most marked differences is that the fault system separating the Gertrud Graben, the Feda Graben and the Heno Plateau becomes locked during the Late Cretaceous/Paleogene while the Ame-Elin trend is strongly inverted.

Observations show that the major inversion structures are often underlain by Zechstein salt. Contemporaneous normal faulting (local extension), however, took place without involvement of salt. The onset of inversion of previously generated structures therefore depended not only on changes in the regional stress system, but also seems to be controlled by the rheology of the rocks involved.

Key words: Strike-slip, quantification, Danish Central Graben, inversion, multiple events.

Ole Rønф Clausen, John A. Korstgård, Geologisk Institut, Aarhus Universitet, 8000 Århus C. Tommy Mogensen Egebjerg, Norsk Hydro a.s., P.O.Box 31, N9401 Harstad, Norge. 2 May 1996.

Flower structures are recognized on seismic sections in many sedimentary basins (Harding 1985) including the Central Graben of the North Sea Basin (Vejbæk \& Andersen 1987). The general interpretation of a flower structure is that it indicates lateral movement along one or more of its fault branches often with a component of compression (transpression) or extension (ranstension) normal to the fault strike (Harding \& Lowell 1979; Harding 1983, 1985)

The near-surface part of a flower structure has a geometry similar to part of a conjugate fault system whereas the deeper part usually is interpreted as a single fault plane on reflection seismic lines. The strain across the upper part of a flower structure therefore seems to be accommodated by formation of structural high and lows. Strain across the lower parts of a flower structure (a single fault plane) can only be accommodated through significant vertical movement along the single fault plane or by complex deformation of the rock volume adjacent to the fault plane due to space problems. Therefore the deformation mechanisms must be different in the upper and lower parts of a flower structure.

Here we develop a model for the accommodation of strain across a flower structure formed during transpression. However, the model should equally apply to transtension. The model is used as a basis for a quantitative strain analysis in which the direction and size of 
the lateral movement across the flower structure are determined. Our model is based on the model presented by Sanderson \& Marchini (1984), but we rewrite the equations so that the size and direction of displacement across a transpressional zone can be calculated based on observations from reflection seismic sections, Modification or supplements to this model has also recently been presented by McCoss (1986), Fossen \& Tikoff (1993), Jones \& Tanner (1995) and Krantz (1995). We apply the model to the Arne-Elin trend in the Danish Central Graben, which during the Late Cretaceous and Paleogene was a NNW-SSE striking inversion zone (Andersen et al. 1982; Vejbæk \& Andersen 1987) with a flower structure geometry (Vejbæk 1986). The possible influence of Zechstein salt, which underlies part of the Arne Elin trend, is also discussed.

\section{Theory and models}

\section{Outline of the model}

Simultaneous slip along two opposite dipping but related faults is difficult because of space problems and will result in intense deformation (crushing if the rocks involved behave in a brittle manner) of the tips of the approaching blocks (Blès \& Feuga 1986, their Fig. 6.6). The evolution of a single preferred fault plane will result only in a transfer of the space problem along the fault plane. The opposite dipping faults defining the outline of a flower structure have a geometry resembling that of a conjugate set of faults and accommodaton strain without crushing in the rock volume between the approaching tips may occur as described by Nadai (1950, p. 551, Fig. 37-27) where "...several parallel strips may cross each other in which the material is distorted by simple shear of variable or uniform intensity and these layers may be separated by domains of the body which remain undistorted and are merely displaced in the X,Y-plane as rigid bodies".

A somewhat similar mechanism is shown by Jaeger \& Cook (1969, p. 92), and Ramsay \& Huber (1987, p. 614). As the width of Nadai's "layers" or "parallel strips" approaches zero, they can be regarded as faults or "brittle shear zones" in the sense of Ramsay \& Huber (1987, p. 595), who also shows (p. 615, Fig. 26.29) how multiple intersecting shear zones can accommodate large bulk strains. Assuming that such faults or shears have a size smaller than the resolution of observation, the bulk deformation can be regarded as a pure shear strain and consequently obeys fairly simple strain laws. Our model therefore assumes that compression in a positive flower structure is accommodated in the upper parts by thrusting and in the lower parts by (bulk) pure shear strain.

Strains related to the bulk deformation will be expressed as a doming at the top because the deformation resembles pure shear strain and obeys the general deformation laws (horizontal shortening results in vertical extension). If the horizontal shortening is concentrated in a fault block with inward dipping faults, and assuming that shortening is constant with depth, the vertical elongation increases with increasing depth and the result is a differential doming of the upper surface as shown by Nadai (1950, p. 551). The doming observed across the transpression zone may thus be explained by a vertical narrowing of the zone of deformation. However, the width of the zone cannot become infinitely thin (a single fault plane) because of space problems.

This model is supported by the sandbox experiments of Emmons (1969), which show that the root of the "flower structure" has a finite width and that there is a degree of plastic deformation in the adjoining volume of rock, especially near the roots of the flower structure. Emmons (1969) also observes that individual fault blocks become subdivided by new generations of faults during deformation to accommodate the growing space problem.

Strain analysis across a zone deformed in transpression

The deformation across a zone where the strain is a combination of simple shear strain and pure shear strain is described by the deformation matrix

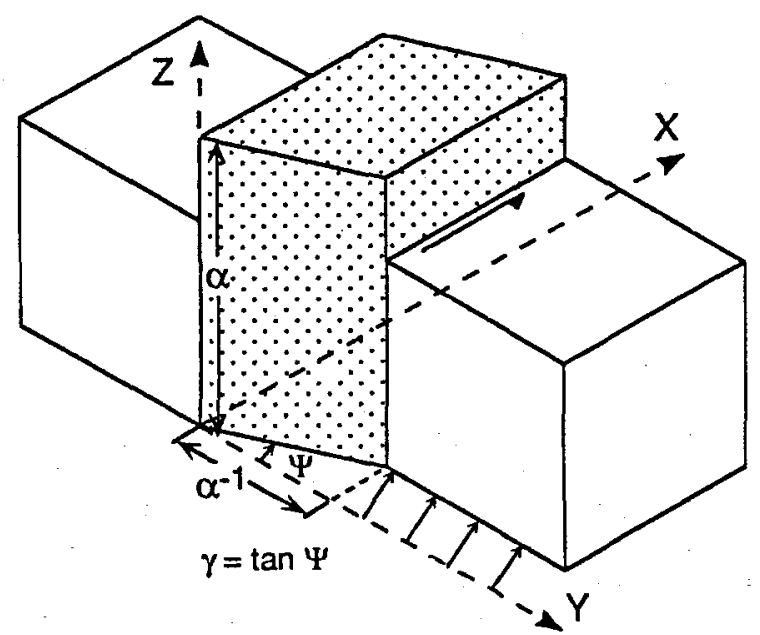

Fig. 1. Geometry of the transpression model used by Sanderson \& Marchini (1984) and in the present work. A cube is deformed by shortening along the $\mathrm{Y}$-axis normal to the $\mathrm{X}-\mathrm{Z}$ plane (the shear plane) and shearing parallel to the $X$-axis within the $X-Z$ plane. The simple shear strain is $\gamma$. The vertical stretch, $\alpha$, which is a function of the pure shear strain, is defined as the present vertical length (height) divided by the initial vertical length (height). In this sketch, the initial vertical length is unity and the present vertical length is therefore $\alpha$. Since the simple shear strain does not change the width of the transpression zone, the width of the transpression zone after deformation equals $\alpha^{-1}$. 
Fig. 2. Vertical section through a transpression zone before and after deformation (a). The orientation of the vertical section with respect to the shear plane is shown in (b). $h, h_{0}, d, d_{0}$ are lengths before and after deformation and their relations to the vertical stretch, $\alpha$, and the horizontal stretch, $\sqrt{\lambda}$, are indicated. The line $S-S^{\prime}$ is the line at which the measurements are made at present, i.e. in the deformed state, and is a material line that is rotated during deformation and initially had an angle of $\Phi$ to the shear plane.

\section{a. Cross section}
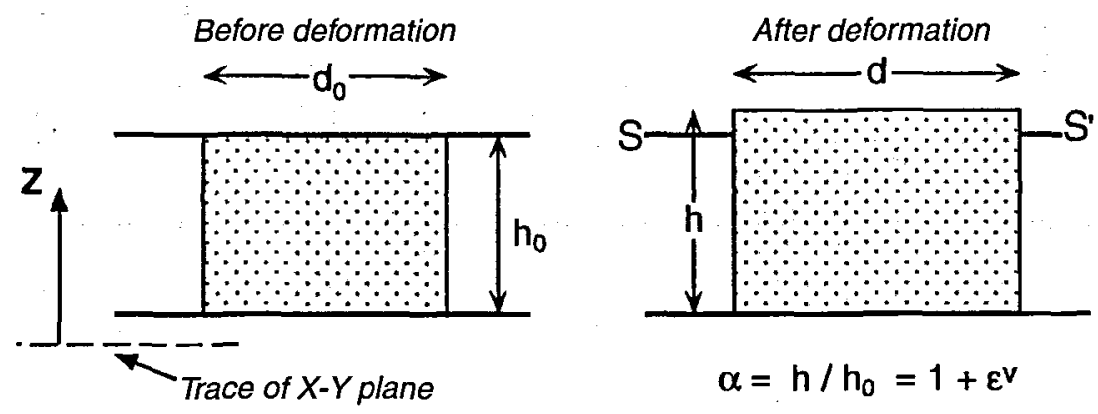

\section{b. Map View}
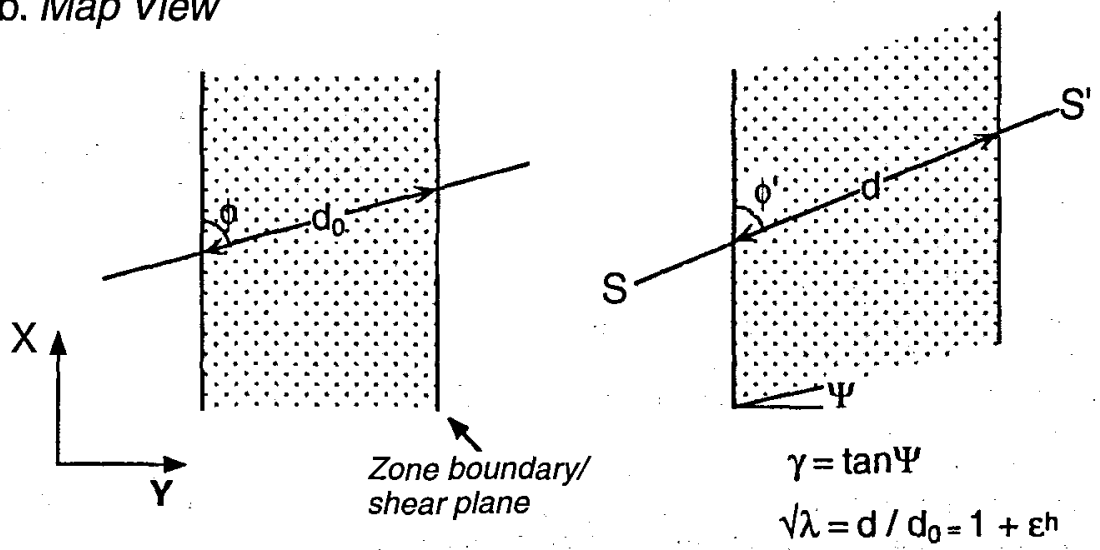

$\mathrm{D}=\left(\begin{array}{lll}1 & \alpha^{-1} \gamma & 0 \\ 0 & \alpha^{-1} & 0 \\ 0 & 0 & \alpha\end{array}\right)$

(Sanderson \& Marchini 1984). The geometric definitions of $\alpha$ and $\gamma$ are shown in figure 1 .

The vertical stretch

$\alpha=\mathrm{h} / \mathrm{h}_{0}$

in the transpression zone (Fig. 2) is the result of the bulk pure shear component, and is the inverse of the stretch normal to the shear plane (the X-Z plane). A value of the vertical stretch less than 1 indicates transtension, whereas a value larger than 1 indicates transpression. The simple shear strain $(\gamma)$ does not contribute to vertical stretch in the zone since the $\mathrm{Z}$-axis lies in the shear plane and is perpendicular to the shear direction (Fig. 1).

Transpressional deformation of a line in the horizontal plane (the X-Y plane, Fig. 1) will stretch the line (i.e. it will introduce a horizontal elongation, $\varepsilon^{\mathrm{h}}$ ) and change the angle between the line and the transpression zone boundary (Fig. 2). The elongation and angular change of any line in the horizontal plane (the $X-Y$ plane) depend on the amount of pure shear strain, simple shear strain and the original angle between the horizontal line and the transpression zone boundary (shear plane). The change of angle expressed in terms of vertical elongation, simple shear strain and original angle is

$$
\cot \Phi^{\prime}=\alpha \cot \Phi+\gamma
$$

where $\Phi$ is the original angle between the line and the shear plane in the undeformed state and $\Phi$ ' is the angle in the deformed state (Fig. 2) (Sanderson \& Marchini 1984).

The quadratic elongation is defined as

$\lambda=\left(1+\varepsilon^{h}\right)^{2}$

and the quadratic elongation of a deformed line in terms of its original undeformed orientation $(\Phi)$ and the strain parameters $\alpha$ and $\gamma$ is

$$
\lambda=1+\left(\alpha^{-2}+\alpha^{-2} \gamma^{2}-1\right) \cdot \sin 2 \Phi+2 \alpha^{-1} \cdot \gamma \cdot \cos \Phi \cdot \sin \Phi
$$

\section{(Sanderson \& Marchini 1984).}

The reciprocal quadratic elongation is the squared length of a line which after deformation is unity

$\lambda^{\prime}=1 / \lambda=1 /\left(1+\varepsilon^{\mathrm{h}}\right)^{2}$.

The reciprocal quadratic elongation as a function of 


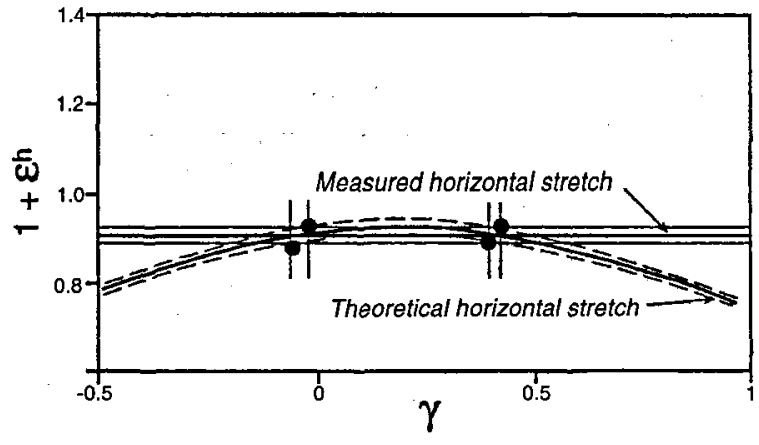

Fig. 3. Diagram showing the theoretical variations of the horizontal stretch as a function of $\gamma$ for known $\alpha$ and $\Phi$ ' as given by equation 7 . Superimposed is the actual measured horizontal stretch and the intersection between the theoretical and measured values gives values of $\gamma$. The sensitivity of the result to the measurements is indicated by the additional curves generated by introducing absolute errors of \pm 0.02 to the measured vertical stretch and to the horizontal elongation. The intersections of the relevant curves are indicated with dots and vertical lines. It is obvious that absolute errors up to \pm 0.02 of the horizontal stretch do do not change the result (the sense of movement and amount of simple shear strain), which is located between the vertical lines, significantly.

$\alpha$ (vertical stretch), $\gamma$ (the amount of simple shear across the zone) and $\Phi$ ' (the angle between the direction of the line in the deformed state and the zone boundary) is also given by Sanderson \& Marchini (1984)

$\lambda^{\prime}=1+\left(\alpha^{2}+\gamma^{2}-1\right) \cdot \sin ^{2} \Phi^{\prime}-2 \gamma \cdot \sin \Phi^{\prime} \cdot \cos \Phi^{\prime}$.

Knowing the values of $\lambda^{\prime}, \alpha$ and $\Phi^{\prime}$ the shear strain $(\gamma)$ across the zone and therefore the relative displacements

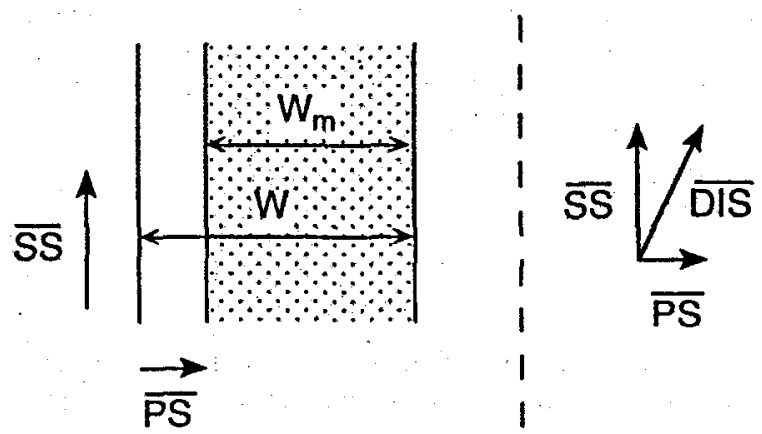

Fig. 4. The vector $\overline{\mathrm{PS}}$ indicates the direction and size of the absolute displacement caused by the change in width of the transpression zone and is related to the measurable width and the pure shear strain as indicated in equation 9 and 11 . The vector $\overline{s s}$ indicates the size and orientation of the absolute displacement caused by simple shear strain, and the relations to the width of the transpression zone and the simple shear strain is given by equation 8 and 11 . The vector $\overline{D I S}$ is the total displacement across the transpression zone obtained by adding the two vectors $\overline{\text { SS }}$ and $\overline{\mathrm{PS}}$. of adjoining blocks across a zone can be calculated. Equation 7 gives 2 solutions for $\gamma$ (Fig. 3). To determine the correct solution one must know the sense of shear of the deformation or compare the results from adjoining sections and use a solution that satisfies an overall picture (the sense of movement along a possible strike-slip zone has to be the same).

\section{Absolute displacement across the zone}

Having determined $\gamma$ and $\alpha$, the displacement parallel to the shear plane, $\overline{\mathrm{SS}}$, and the displacement normal to the shear plane, $\overline{\mathrm{PS}}$, can be calculated from

$\overline{\mathrm{SS}}=\mathrm{W} \cdot \gamma \cdot \overline{\mathrm{e}_{\mathrm{x}}}$

and

$\overline{\mathrm{PS}}=\mathrm{W} \cdot(\alpha-1)^{-1} \cdot \overline{\mathrm{e}_{\mathrm{y}}}$

where $\mathrm{W}$ is the initial width of the zone (normal to the shear plane and parallel to the $Y$-axis) before the imposed deformation (Fig. 4), $\overline{\mathrm{e}_{\mathrm{x}}}$ and $\overline{\mathrm{e}_{\mathrm{y}}}$ are unit vectors of the $\mathrm{X}$-axis and $\mathrm{Y}$-axis respectively.

The displacement vector across the transpression zone, $\overline{\mathrm{DIS}}$, is the vector sum of $\overline{\mathrm{SS}}$ and $\overline{\mathrm{PS}}$ (Fig. 4), and the scalar value or the magnitude of the displacement is

DIS $=\mathrm{W} \cdot \sqrt{(\alpha-1)^{-2}+\gamma^{2}}$

The measurable width, which is the width of the deformed zone is

$\mathrm{Wm}=\mathrm{W} \cdot \alpha^{-1} \Rightarrow \mathrm{W}=\mathrm{W}_{\mathrm{m}} \cdot \alpha$

so the magnitude of the displacement becomes

DIS $=\mathrm{Wm} \cdot \alpha \cdot \sqrt{(\alpha-1)^{-2}+\gamma^{2}}$.

\section{Multiple deformations}

Consider three sequence boundaries (horizons) A, B and $C$ (Fig. 5) and two deformation phases F1 and F2 where $F 1$ is older than F2. Assume that A, B and C were horizontal when deposited, and that sequence boundaries $B$ and $C$ are older than $F 2$ and that the age of sequence boundary $A$ is between the two deformation phases. This means that the sediment succession between $B$ and $C$ is deformed during phase $F 1$ and F2 in contrast to the succession between A and B which only suffered deformation during $\mathrm{F} 2$.

In a given vertical section the horizontal stretch can be determined along the A-horizon and the B-horizon (Fig. 5). The shape of the A-horizon reflects the deformation (F2) introduced after deposition of the A-horizon whereas the shape of the B-horizon reflects both the $F 1$ and $F 2$ deformation phases. The stretch values 
Fig. 5. Cross section through a transpression zone that has suffered two deformation phases (a). Map view of the top of the B-horizon which has suffered two deformation phases (b). The map view at the B-horizon shows how the lengths change during the progressive deformation. The different steps, before $\mathrm{F} 2$ and before $F 1$ show how the values change. The notation used is similar to the notation in equation 7 . The equations 3,7 , 13 , and 14 are used to remove the effect of $\mathrm{F} 2$ on the stretch values of the $\mathrm{B}-\mathrm{C}$ interval giving the stretch values of $F 1$. The F1 stretch values and the angle $\Phi 1$ ' are used to determine the simple shear strain of F1. a. Cross section

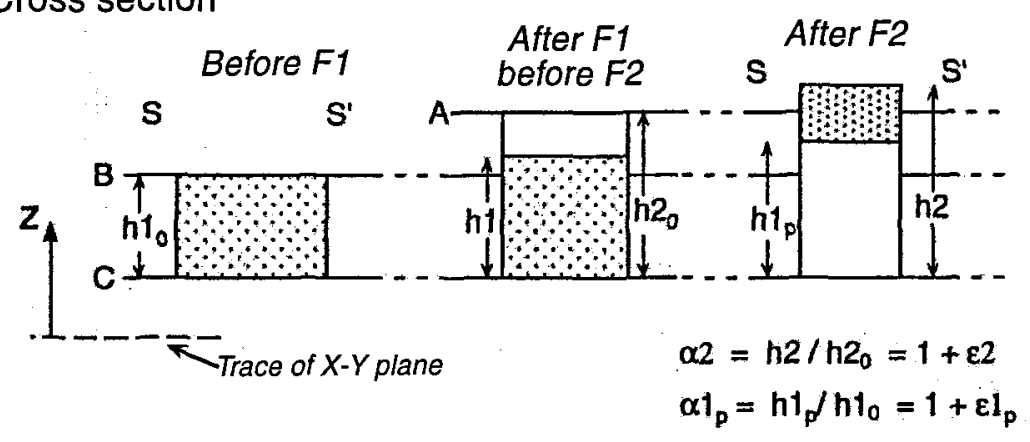

b. Map View

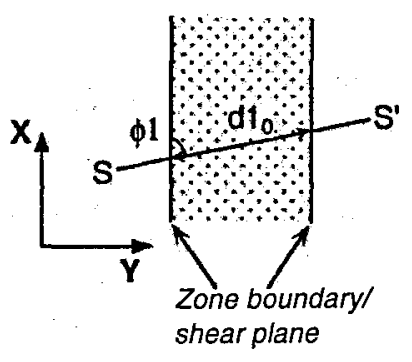

determined along the A-horizon thus indicates the intensity of deformation $\mathrm{F} 2$ whereas the stretch values determined along the B-horizon indicates the combined intensity of the deformation phases F1 and F2. The present vertical stretch and thus vertical quadratic elongation of the successions C-B and C-A can also be obtained as shown in Figure 5.

Given the angle between shear plane and cross section and the stretch values from the succession A-C (determined from the cross section as described later) it is possible to determine the strain parameters $\gamma_{2}$ and $\alpha 2$ characterizing the latest deformation phase $F 2$ as described in the previous sections.

The stretching (vertical and horizontal) induced to the succession C-B during the first deformation phase F1 can be obtained by removing the effect of F2. However, it is important to note that the angle between the vertical sections in which the stretch values are obtained and the shear plane changes when removing the effect of the latest deformation due to the rotational nature of the simple shear involved.

The true stretching of the F1 deformation is obtained in the following way:

a: $\gamma 2$ with opposite sign and the reciprocal of $\alpha 2\left(\alpha 2^{-1}\right)$ are used in equations 3 and 5 to get $\Phi 2$ and $\lambda^{r}$ ( $\Phi 2$ is the angle between the shear plane and the vertical section before $F 2$ but after $F 1$, and $\lambda^{r}$ is the quadratic elongation of a vector which is a unit vector oriented at an angle $\Phi 2$ ' to the shear plane (Fig. 5)). $\mathrm{b}$ : The value $\lambda^{\mathrm{r}}$ is then used to remove the latest deformation, $F 2$, from the horizontal stretch values $\gamma 1$ measured on the C-B succession, so that the quadratic elongation in the direction $\Phi 2$ to the shear plane before the latest deformation is

$\lambda 1=\lambda 1_{p} \cdot \lambda^{r}$

c: Using the deformation matrix (equation 1) the latest deformation, $\mathrm{F} 2$, is removed from the measured vertical stretch $\left(\alpha 1_{p}\right)$ by multiplying the measured vertical stretch with $\alpha^{p^{p}}=\alpha 2^{-1}$,

$\alpha 1=\alpha 1_{p} \cdot \alpha^{\mathrm{r}}=\alpha 1_{\mathrm{p}} \cdot \alpha 2^{-1}$

since the Z-direction lies within the shear plane and therefore is unaffected by the simple shearing.

The values $\Phi 1^{\prime}, \lambda 1$, and $\alpha 1$ obtained are unaffected by the latest deformation and show only the deformation introduced by the earliest deformation (F1). Therefore the values can be used in a way similar to the data from $\mathrm{F} 2$ in equation 5 to obtain the simple shear strain, $\gamma 1$, which, together with $\alpha 1$ gives the displacement across the transpression zone during the earliest deformation $\mathrm{F} 1$. 
Location of the shear plane

The orientation of the shear plane is critical for determining the absolute amount and direction of movement across a shear zone. From real data sets (fault maps) it is often a fairly simple procedure to determine the approximate location and orientation of a shear plane. The most likely location is parallel to the overall strike of a faulted zone, since this expresses the boundary of the deformed zone which is also parallel to the shear plane (Sanderson \& Marchini 1984).

\section{Obtaining data from seismic sections}

To perform the strain analysis outlined above on transpression structures observed on seismic sections one must know :

a: the orientation of the vertical section $\left(\Phi^{\circ}\right)$ with respect to the transpression zone boundary

b: the horizontal stretch along the top of the deformed succession (giving $\lambda$ or $\lambda^{\prime}$ )

c: the vertical stretch $(\alpha)$ of the deformed succession.

This information is obtained directly from interpreted seismic sections and from fault maps. A mapped horizon on a seismic line crossing a transpression zone represents a line that before transpression was assumed undeformed and linear.

However, the line has been rotated and originally had a different orientation with respect to the shear plane/transpression zone boundary. Because the stretch is dimensionless and assuming that the seismic velocities are constant over the measured distances, is it possible to use the standard relations between horizontal and vertical strain in spite of the fact that on seismic sections the horizontal scale is in meters and the vertical scale is in seconds two way travel time.

The model of Sanderson \& Marchini (1984) implies

\section{Horizontal stretch}

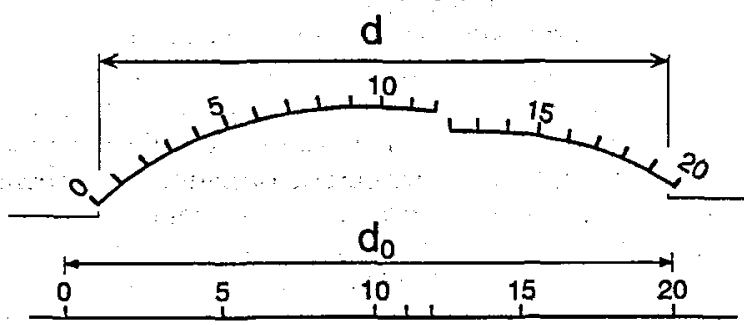

Fig. 6. Determination of the horizontal elongation across a transpression zone. $d_{0}$ is the initial horizontal length of a reflector measured by adding the length of different segments taking faulting and curvature of the horizon into account. $\mathrm{d}$ is the present horizontal length measured between the transpression zone boundaries. vertical boundaries of the deformation zone and homogeneous deformation. It is possible to approximate the inhomogeneous deformation observed across a flower structure to a homogeneous deformation as described below.

Orientation of the vertical section (the seismic section): Because $\Phi^{\prime}$ is an important parameter in equation 7 it is critical that the orientation of the shear plane is determined as accurately as possible. The angle between the section and the shear plane, $\Phi^{\prime}$, is measured directly as the angle between the seismic section and the shear plane. On fault maps, the shear plane is generally parallel, not to individual faults, but to the overall strike of the fault zone or parallel to the trend of an array of én echelon faults (Harding 1985).

\section{Horizontal stretch}

The horizontal stretch, $\sqrt{\lambda}$, of a horizon is given by

$\sqrt{\lambda}=1+\varepsilon^{\mathrm{h}}=\mathrm{d} / \mathrm{d}_{0}$

where $d$ is the present measured length of the horizon and $d_{0}$ the original length (Fig. 6).

The present horizontal distance, $\mathrm{d}$, is measured horizontally across the zone of deformation either from measurements on faults that separate the deformed part of the horizon from the non-deformed, or from points just outside the deformed part of the horizon or from a combination of both. The original length, $\mathrm{d}_{0}$, is given as the accumulated length of the deformed parts of the horizon (Fig. 6).

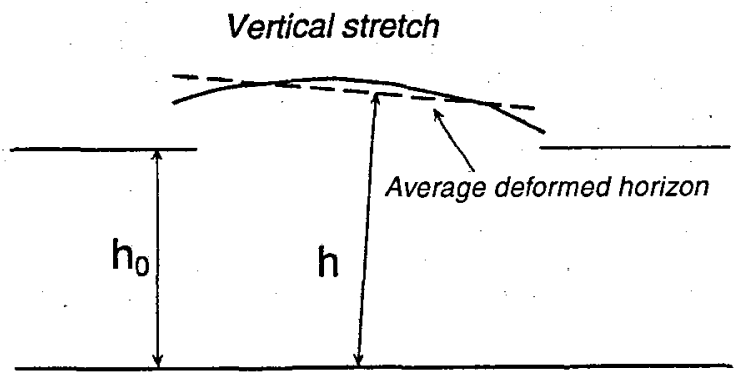

Fig. 7. Determination of the vertical elongation in a transpression zone. $h_{0}$ is the initial vertical length measured from a reference level and $h$ is the present vertical length measured from the reference level to an average deformed horizon. 


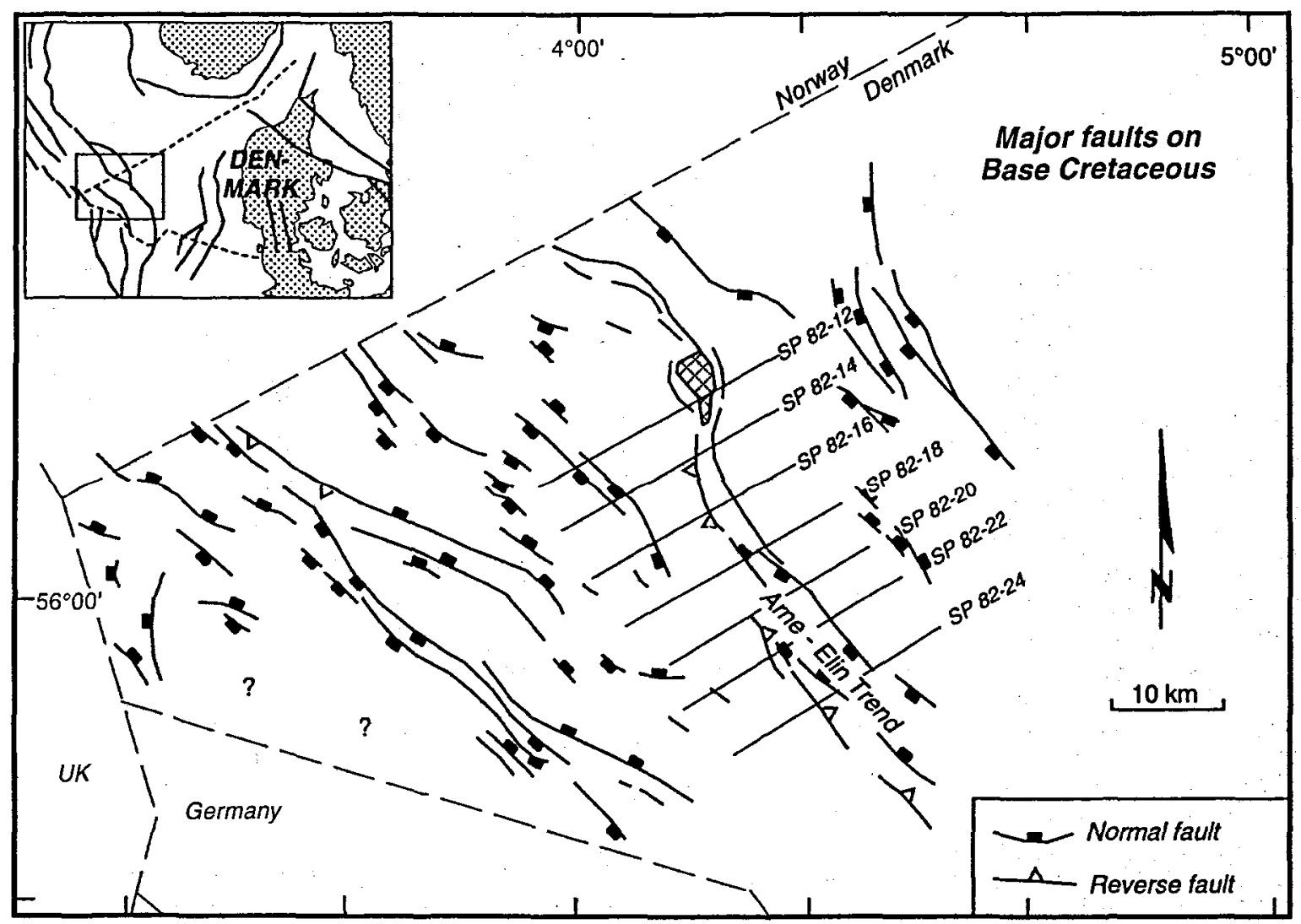

Fig. 8. Simplified fault map of the Base Cretaceous. Compiled from Vejbak (1986), Mogensen (1988) and Mikkelsen (1988). SP 82-12 etc. are seismic lines used.

\section{Vertical stretch}

The vertical stretch $\alpha$ is given by

$\alpha=h / h_{0}$

where $h$ is the vertical distance between a horizon and a reference level, and $h_{0}$ is the original distance between a horizon and the reference level (Fig. 7).

The present vertical distance is measured in the deformed zone at intermediate angles to an "average" deformed horizon and the reference level (Fig. 7). The average deformed horizon is a straight line which equals a linear approximation of the deformed horizon. The average deformed horizon must be used since the calculations are based on a homogenous distribution of the deformation across the deformed zone.

\section{Transpression across the Arne-Elin trend}

The Arne-Elin trend is situated in the northern part of the Danish Central Graben and is one of the most clearly outlined "inversion structures" in the area (Fig.
8). The structure was first identified as a transpressional feature by Andersen et al. (1982) and positive flower structures were shown by Vejbæk (1986). The area has been mapped using seismic data by several investigators (Cartwright 1987, 1989; Gowers \& Sæbøe 1985; Mikkelsen 1988; Mogensen 1988; Vejbæk 1986; Vejbæk \& Andersen 1987), and there is general agreement among these authors in the mapping of faults, and about the dating of the seismic boundaries.

The seismic mapping by Mogensen (1988) was used in this study and the vertical and the horizontal stretch ( $\alpha$ and $\sqrt{\lambda}$, equations $15 \& 16$ ) were obtained along seven sections across the trend (Fig. 8). Measurements were carried out for two major periods (Early Cretaceous and post-Early Cretaceous) during which there were tectonic activity along the Arne-Elin trend. The horizontal stretch was measured along the horizon representing the Top Lower Cretaceous (TLC) boundary and on the Late Cimmerian Unconformity (LCU), both of which were assumed to have been horizontal before deformation. The quadratic elongation $\lambda_{\mathrm{LCu}}$ is thus an expression of post-Jurassic deformation while $\lambda_{\mathrm{TLC}} \mathrm{ex}-$ presses only the post-early Cretaceous deformation (Fig. 9).

Ideally measurements of vertical stretch should be 


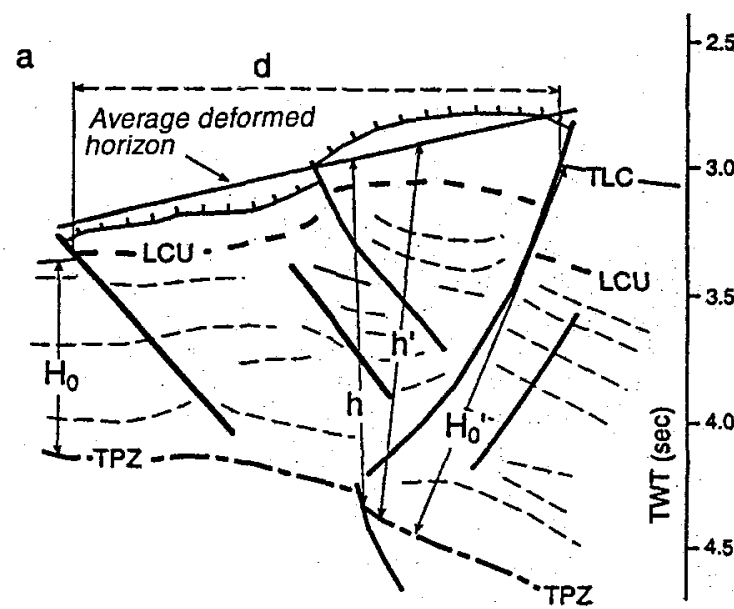

b

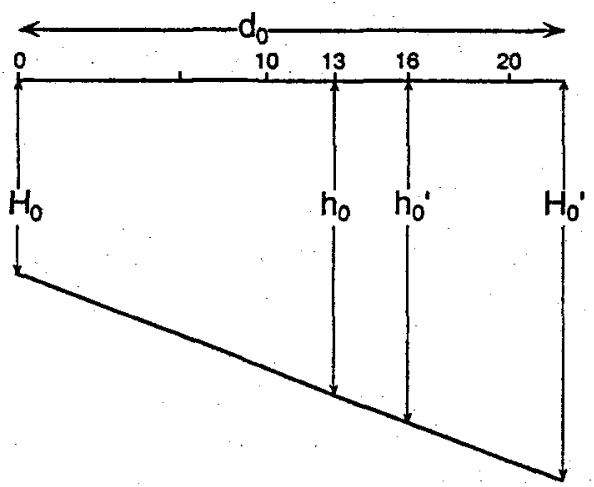

Fig. 9. Interpreted seismic section (SP82-16) across the Arne Elin trend and the measurement locations (a). The present depth in two way time of the transpression structure is shown to the right and the location of the Top Pre-Zechstein (TPZ), the Late Cimmerian Unconformity (LCU), and the Top Lower Cretaceous (TLC) horizons are shown. The values for obtaining the vertical stretch are measured at several locations to obtain a better approximation of a uniform deformation. The retro-deformed section showing positions of length measurements and the initial lengths (b).

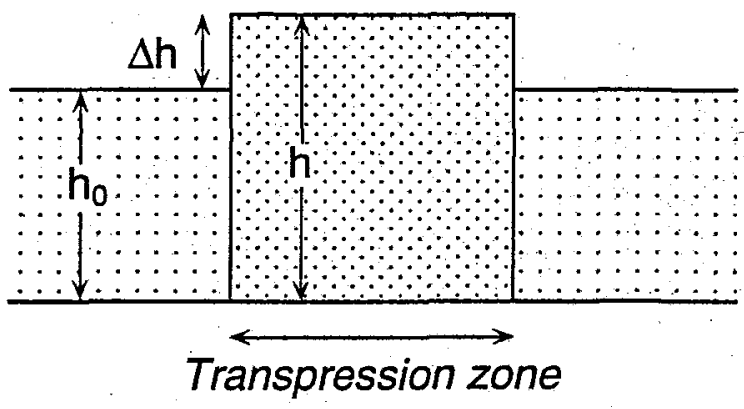

$$
\begin{gathered}
\alpha=\mathrm{h} / \mathrm{h}_{0} \\
\text { Depth converted stretch } \\
\alpha_{\mathrm{d}}=\mathrm{h} \cdot \mathrm{v} / \mathrm{h}_{0} \cdot \mathrm{v}=\alpha
\end{gathered}
$$

Fig. 10. The effect of depth converting outside and within a transpression zone. See text for further explanation. a

\section{Compacted section}

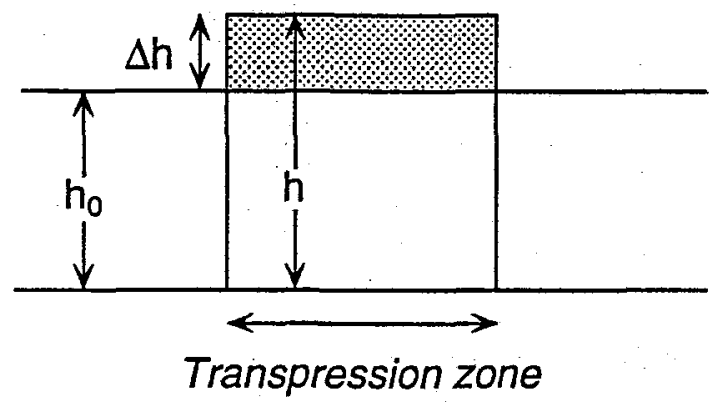

Compacted $b \% \quad$ Compacted a.\%

$$
\alpha=h / h_{0}
$$

b

\section{Decompacted section}

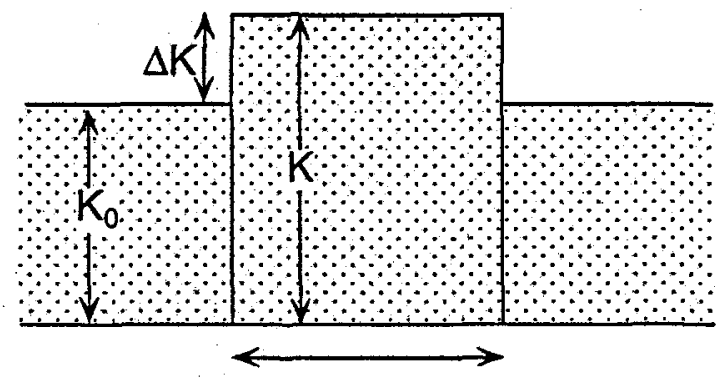

Transpression zone

$$
\alpha_{\text {dec }}=K / K_{0}
$$

Fig. 11. Compacted section across a transpression zone where there are differences in compaction above and below the regional top of the sequence (a). The differential compaction is obtained when a topography created by transpression is buried. The compaction before transpression is the same above and below the regional top of the sequence. The relations between the compacted lengths and the vertical stretch, $\alpha$, is shown. b. Section across a transpression zone where the sediments deposited after transpression are removed and the sequence is decompacted (b). Relations between the decompacted vertical lengths and the decompacted vertical stretch, $\alpha_{\mathrm{dec}}$, is shown.

performed on geological sections i.e. depth converted and decompacted seismic sections. However, as illustrated in figure 10 the usual methods of depth conversion (adopting the seismic velocity for a sequence from a nearby well to a sequence throughout a section) would not introduce any changes in the measured stretch.

The effect of compaction of the sediments in a transpression zone for the observed vertical stretch is shown in figure 11. The compaction is assumed to be 
uniform i.e. the compaction of a given sediment at a given depth is similar inside and outside the transpression zone. This means that the sediments within the transpression zone and located below the regional top of the sequence (Fig. 11) will be compacted to the same degree as the sediments outside the transpression zone. The sequence located above the regional is compacted less than the underlying when the deformed zone is buried. If the compaction of the lower part in the transpression zone, which equals the average compaction outside the transpression zone equals a $\%$ and the average compaction, $\mathrm{b} \%$, above the regional inside the transpression zone equals $\mathrm{b} \%$, then

$a>b$

The observed vertical stretch, $\alpha$, in the compacted section (Fig. 11a) is

$\alpha=h / h_{0}=1+\Delta h / h_{0}=1+\varepsilon_{v}$

The decompacted vertical length can be expressed by the observed compacted length $h_{0}$ and the average compaction $a$

$\mathrm{K}_{0}=\mathrm{h}_{0} \cdot 100 /(100-a)$

whereas the decompacted vertical length, $\mathrm{K}$ in the deformed transpression zone is

$\mathrm{K}=\mathrm{h}_{0} \cdot 100 /(100-a)+\Delta \mathrm{h} \cdot 100 /(100-b)$.

Combining equations 18-20 the decompacted vertical stretch is

$\alpha_{\mathrm{dec}}=1+\varepsilon_{\mathrm{v}} \cdot(100-a) /(100-b)=1+\varepsilon_{\mathrm{v}} \cdot \mathrm{C}=1+\varepsilon_{\mathrm{v}-\mathrm{dec}}$,

where

$\mathrm{C}=(100-a) /(100-b) \geq 1$

according to equation 17 .

The decompacted elongation, $\varepsilon_{\mathrm{v} \text {-dec}}$, is therefore smaller than the compacted elongation $\varepsilon_{\mathrm{v}}$ by a factor $\mathrm{C}$ determined by the difference between $a$ and $b$. The difference between $a$ and $b$ decreases with increasing burial depth since the reduction in porosity decreases with increasing total burial depth (Sclater and Christie 1980). The total burial depth of the horizons Top Lower Cretaceous (TLC) and Late Cimmerian Unconformity (LCU) along the Arne-Elin trend is on average $3 \mathrm{~km}$ below the present sea level. The difference in depth of the top of the horizon within the transpression zone and outside the transpression zone is approximately $500 \mathrm{~m}$. From the porosity curve of Sclater and Christie (1980, Fig. A2 and A3) it can be seen that the difference in compaction above and below the regional will be less than $10 \%$. Assuming a situation where $a=40 \%$ and $b=35 \%, C$ attains a value of 0.909 . Correcting
Table 1. The stretch values calculated as shown in figures 2 and 5 are given for seven sections across the Arne-Elin trend (Fig. 8). The angle $\Phi 2^{\prime}$ is $80^{\circ}$.

$\alpha 2$. Vertical stretch between TPZ and TLC.

$1+\varepsilon 2$ Horizontal stretch along the TLC surface

$\alpha 1 \quad$ Vertical stretch between TPZ and LCU

$1+\stackrel{p}{e} 1_{p}$ Horizontal stretch along the LCU surface.

\begin{tabular}{|l|l|l|l|l|}
\hline & $\alpha 2$ & $1+\varepsilon 2$ & $\alpha 1_{p}$ & $1+\varepsilon 1_{p}$ \\
\hline SP82-12 & 1.04 & 0.97 & 1.04 & 0.96 \\
\hline SP82-14 & 1.10 & 0.79 & 1.25 & 0.8 \\
\hline SP82-16 & 1.14 & 0.87 & 1.08 & 0.93 \\
\hline SP82-18 & 1.06 & 0.94 & 0.95 & 1.04 \\
\hline SP82-20 & 1.07 & 0.97 & 0.92 & 1.05 \\
\hline SP82-22 & 1.06 & 0.98 & 0.90 & 1.05 \\
\hline SP82-24 & 1.06 & 0.98 & 0.92 & 1.06 \\
\hline
\end{tabular}

the vertical stretch, $\alpha$, with this factor has no significance as the smallest measured vertical stretch of 1.04 will be corrected to 1.036 and the maximum measured vertical stretch will change from 1.14 to 1.13 . The effect of compaction is thus neglected in this study.

The vertical stretch $(\alpha)$ is measured on seismic sections using the Top Pre-Zechstein (TPZ) as a reference level (Fig. 9), i.e. $\alpha_{L C U}$ is the stretch between the LCU and TPZ seismic boundaries and $\alpha_{\mathrm{TC}}$ is the stretch between the TLC and TPZ sequence boundary. The stretches calculated from the direct measurements are listed in Table 1.

There is general agreement among previous investigators about the discontinuity of faults within the ArneElin trend, and also that strike directions of individual

Table 2. The pure shear strain and simple shear strain values calculated for each section examined across the ArneElin trend. The results are used for calculating the absolute displacement vectors shown in figures 12 and 14.

$\alpha 2$ Vertical stretch between TPZ and TLC i.e. the pure shear strain of the latest deformation

$\gamma 2$ Simple shear strain of F2

$\alpha 1$ The pure shear strain of $\mathrm{F} 1$

$\gamma 1$ The simple shear strain of Fl

\begin{tabular}{|l|c|c|c|c|}
\hline & $\alpha 2$ & $\gamma 2$ & $\alpha 1$ & $\gamma 1$ \\
\hline SP82-12 & 1.04 & 0.3 & 1.00 & 0.32 \\
\hline SP82-14 & 1.10 & 0.35 & 1.14 & -0.5 \\
\hline SP82-16 & 1.14 & 0.45 & 0.95 & -0.42 \\
\hline SP82-18 & 1.06 & 0.39 & 0.89 & -0.42 \\
\hline SP82-20 & 1.07 & 0.18 & 0.86 & -0.30 \\
\hline SP82-22 & 1.06 & 0.18 & 0.87 & -0.35 \\
\hline SP82-24 & 1.06 & 0.18 & 0.87 & -0.27 \\
\hline
\end{tabular}




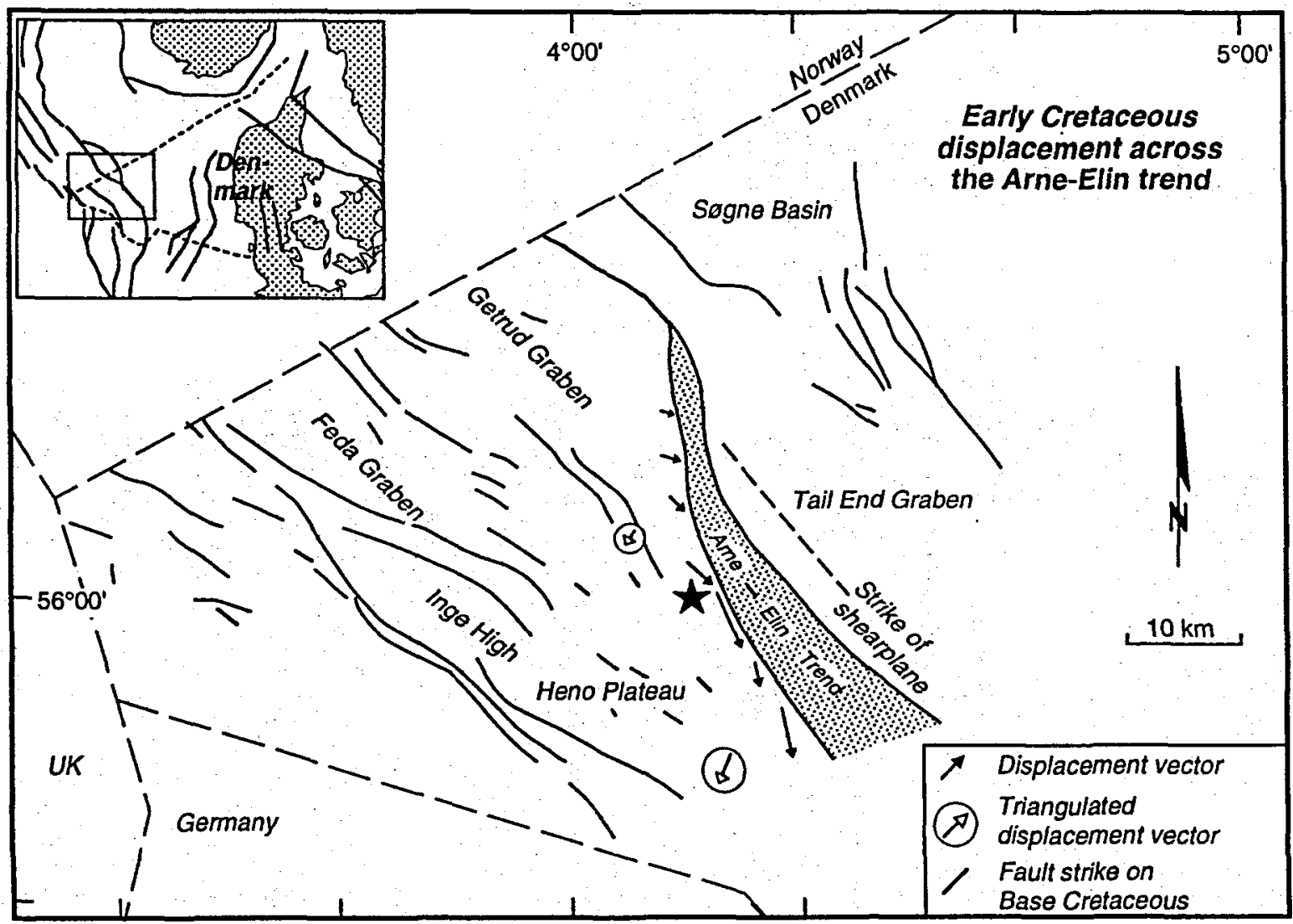

Fig. 12. The map shows the displacement vectors during Early Cretaceous time across the Arne-Elin trend. The Tail End Graben is held fixed, and the displacement vectors show sinistral displacement across the Arne-Elin trend with the Gertrud Graben and Heno Plateau moving to the left when viewed from the fixed Tail End Graben. Note that the major changes in direction and size of displacements coincide with the intersection of the fault zones between the adjacent blocks and the Arne-Elin trend (marked with asterisk). The triangulated displacement vector are encircled. The scale of the displacement vectors is 3 times the map scale.

faults are inclined to the general orientation of the ArneElin trend. A shear plane parallel to the general trend of the fault system, as indicated in Figure 12, was selected in this study. From the measured angles between the shear plane and the seismic sections the horizontal stretch $\left(\sqrt{\lambda_{\text {TLC }}}\right)$, the vertical stretch $\left(\alpha_{\text {TLC }}\right)$, and the simple shear strain $\left(\gamma_{2}\right)$ of the post-Lower Cretaceous deformation at each section is calculated using equation 7. The results are given in Table 2.

The strain values for the LCU level are retro-deformed using equations $3,5,13$ and 14 , giving the stretch introduced to the pre-LCU during the first deformation phase $(F 1)$ and the angle between the material line and the shear plane after the F1 deformation. The simple shear strain $(\gamma 1)$ of the deformation phase F1 is calculated from equation 7 , and the results are given in Table 2. Figure 3 shows the relation between the actual horizontal stretch and the theoretical variation of the horizontal stretch as a function of $\gamma$. Superimposed on the figure is $a \pm 0.02$ variation of both the horizontal and the vertical stretch, which indicates the sensitivity of the results to the uncertainties in measurements. The figure indicates that in some cases there is a possibility for very large errors in the determination of the shear strain due to small deviations in the determined stretch. However, as shown in this example the variations are in most cases of minor importance.

As indicated in Figure 3 gives equation 7 two solutions for $\gamma$, and one of these should be preferred. The Arne-Elin trend was recognized as a zone of right lateral movements during the Late Cretaceous and the tertiary by Gowers \& Sæbøe (1985); Vejbæk (1986); Vejbæk \& Andersen (1987), and as a zone of left lateral movement during the Late Jurassic and Early Cretaceous by Gowers \& Sæbøe (1985); Møller (1986); Vejbæk (1986). A detailed map (Fig. 13) of the preEarly Cretaceous surface displays minor extensional structures (Mogensen 1988), and the fault pattern within the transpression zone indicate a left lateral movement across the Arne-Elin trend which is in agreement with the interpreted left lateral movement during 


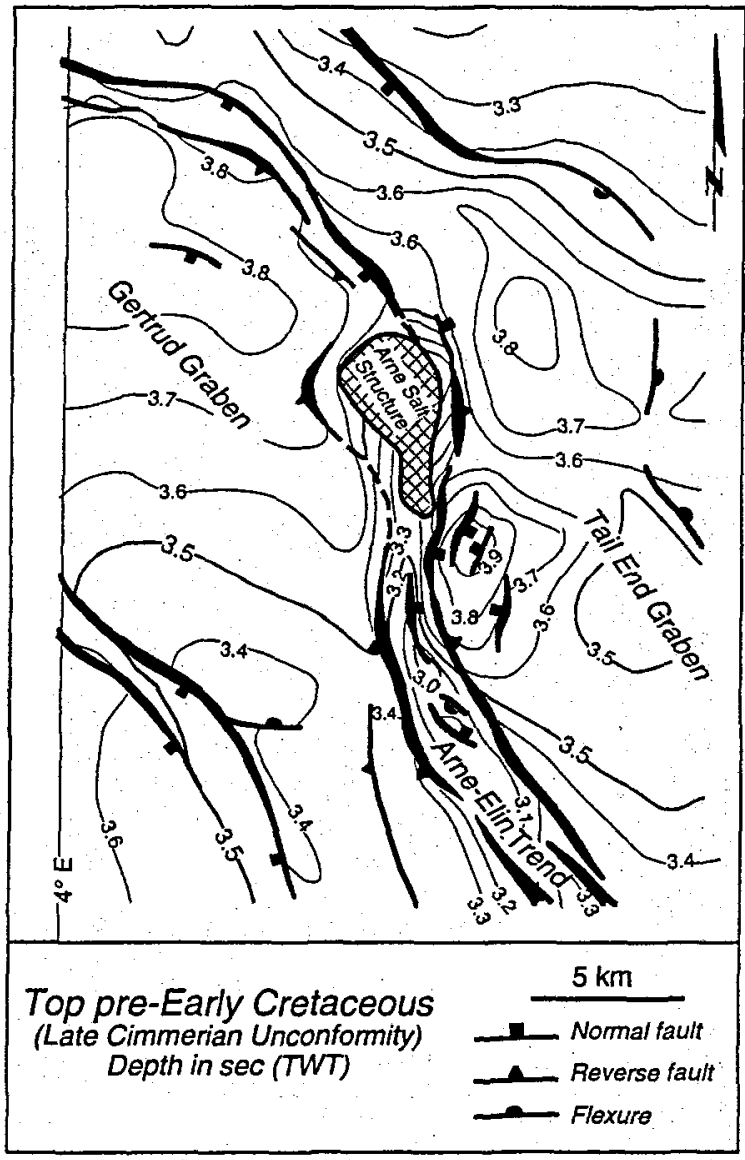

Fig 13. Fault map of the Top Pre-Lower Cretaceous surface (Late Cimmerian Unconformity) showing details of the Arne-Elin trend with a focus on minor faults. The orientation and extension direction of the minor faults within the Arne-Elin trend with respect to the orientation of the ArneElin trend corresponds to a left lateral displacement across the zone (cfr. Sanderson \& Marchini, 1984, Fig. 11).

the Early Cretaceous. The interpreted directions of movement during the Early Cretaceous and the postLate Cretaceous is adopted in this work.

The absolute displacement across the zone during the Late Cretaceous/Paleogene and the Early Cretaceous defined $i$ each section is calculated using equations 8-12 and is displayed as displacement vectors on Figures 12 and 14 for the respective deformation phases. The displacement vectors are positioned along the western boundary of the Arne-Elin trend, and show the size and direction of the displacement across the Arne-Elin trend at each location. Note that the length of the vectors is exaggerated compared to the map scale, since the displacements are so small that the difference in direction and size along the Arne Elin trend would be obscured due to the map-scale used here.

The Early Cretaceous displacement vectors (Fig. 12) show that the Gertrud Graben block has been trans- ferred about $1 \mathrm{~km}$ in an east-south-easterly direction relative to the Tail End Graben, creating an area of transpression south of the Arne structure. However, the displacement of the southern part of the Gertrud Graben Block is more towards the south-east in contrast to the east-south-easterly displacement of the northern part. South of the Gertrud Graben the displacement is south-east to south-south-east causing the southernmost part of the Arne-Elin trend to undergo extension and giving rise to the initial graben-like evolution of the Arne-Elin trend (Vejbæk 1986).

The post-Early Cretaceous displacement across the Arne-Elin trend (Fig. 14) is characterized by a fairly similar right lateral displacement along the southern part of the Arne-Elin trend. Where the boundary between the Feda-Graben and the Gertrud Graben projects into the Arne-Elin trend, there is a clockwise rotation of the displacement vector compared to the displacement vectors at the southern part of the ArneElin trend.

\section{Discussion of the displacement}

The calculated displacement across the Arne-Elin trend gives a minimum value, since the model does not account for the displacement along fault planes which are parallel to the main shear plane. The dis-continuity of the major faults observed in the area implies that regional strike-slip movement parallel to the fault planes is unlikely, and that the calculated displacement therefore provides a fairly good approximation to the total displacement.

The systematic change in displacement across the Arne-Elin trend during the two periods must be viewed in relation to the general structural subdivision of the Danish Central Graben (Gowers \& Sæbøe 1985; Vejbæk 1986) during the Early Cretaceous. The structural events divided the Danish Central Graben into a number of graben units which moved relative to each other.

Triangulation of displacement is based on the principle that changes in size and direction of displacement along a transpression zone will be reflected in deformation of the area adjacent to the transpressional zone (Fig. 15). The strain introduced to the adjacent area may be accommodated by (i) strike-slip movements along faults parallel to the border of the transpressional zone; (ii) diffuse deformation of the adjacent area by slip on minor faults; (iii) generation or reactivation of major fault zones located at an angle to the border of the transpressional zone.

Since there are no major faults recorded along the Arne-Elin trend in the Tail End Graben, it seems most likely that the changes in displacement are reflected in movement along the faults separating the Gertrud Graben, the Feda Graben, and the Heno Plateau.

Triangulation of the different displacement vectors 


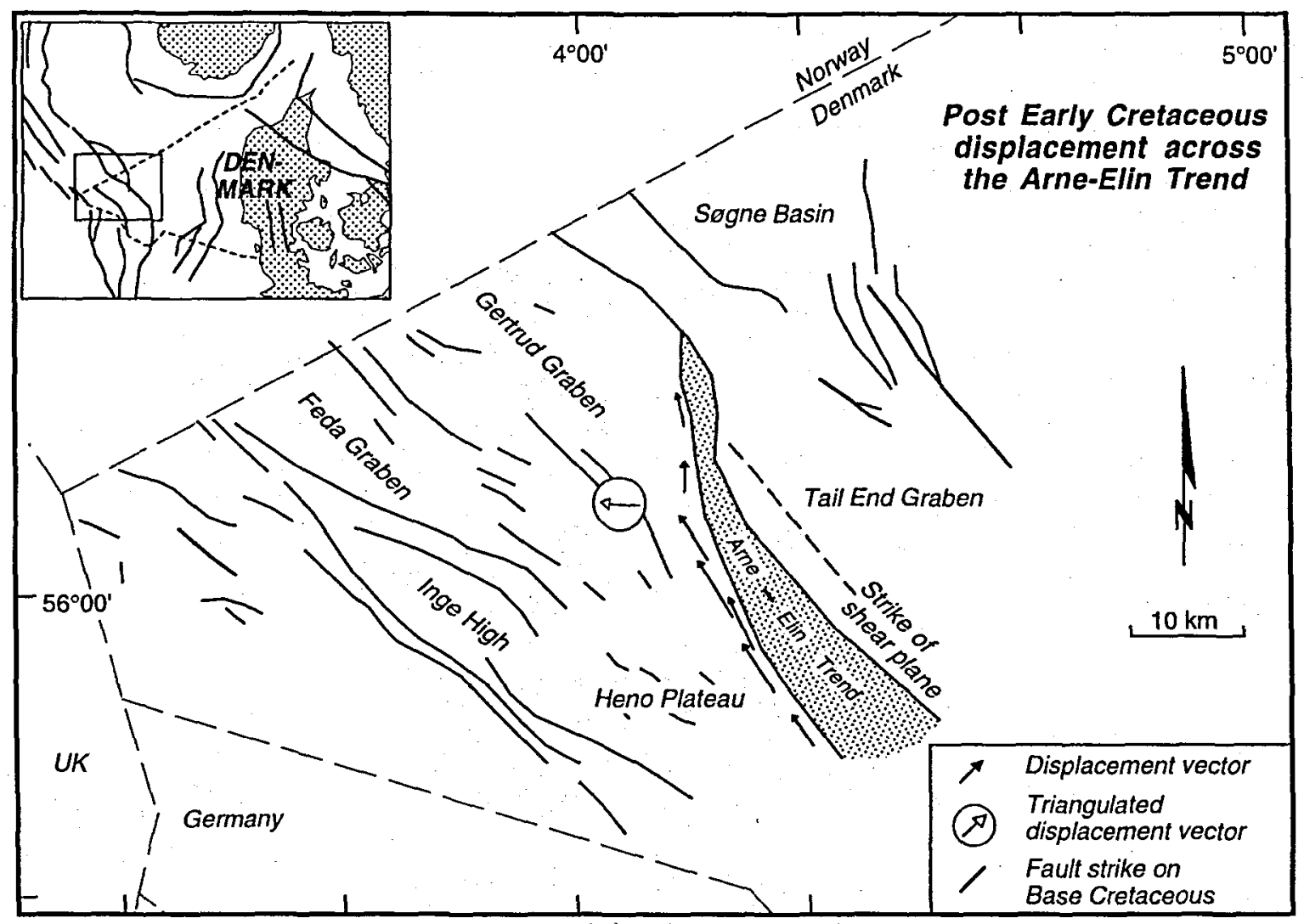

Fig. 14. Displacement vectors in post Early Cretaceous time across the Arne-Elin trend. The Tail End Graben is fixed, and the displacement vectors show dextral displacement across the Arne-Elin trend during the Late Cretaceous and tertiary. Note the change in direction of the displacement vectors at the extension of the border faults between the Feda Graben and the Gertrud Graben into the Arne-Elin trend. The triangulated displacement vector is encircled. The scale of the displacement vectors is 3 times the map scale.

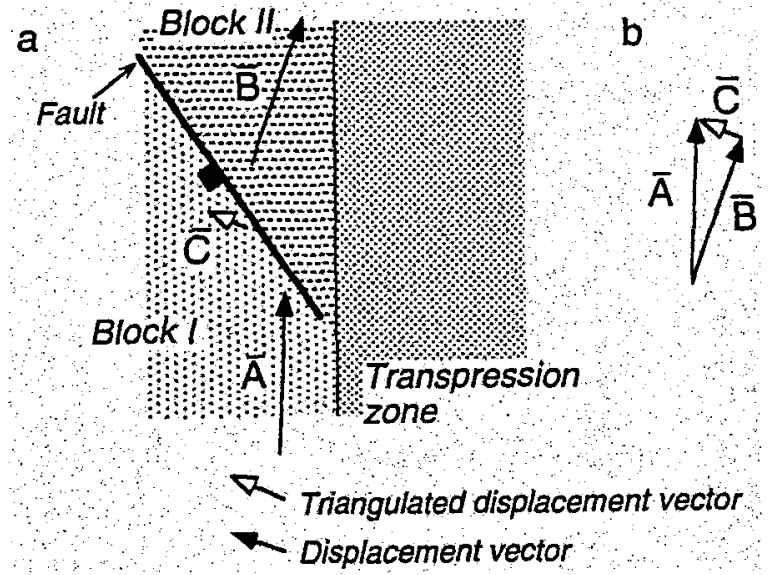

Fig. 15. Two displacement vectors $\overline{\mathrm{A}}$ and $\overline{\mathrm{B}}$ along a transpression zone show a difference in displacement between Block II and the transpression zone and Block I and the transpression zone (a). The difference, which equals the vector $\bar{C}$ as shown in (b) shows that there was displacement between the two blocks along/across the fault separating them, a displacement corresponding to the triangulated displacement vector $\overline{\mathrm{C}}$. of the Early Cretaceous displacement shows that a small extension with a sinistral sense at the FedaGertrud boundary fault may explain the change in direction of the displacement to the south. Furthermore, triangulation between the southern displacement vector of the Gertrud Graben and the southernmost displacement vector ("Heno Plateau" and Tail-End Graben displacement) gives an accumulated displacement for the southern part of the "Heno Plateau" with respect to the Gertrud Graben block (Fig. 12). This triangulated displacement vector is normal to the boundary faults of the Inge High - Feda Graben and to the fault trend on the "Heno Plateau", which is located in the extension of the Inge High/Feda Graben boundary faults.

The displacement along the Arne-Elin trend during the post-Early Cretaceous can be subdivided into a mean northern displacement vector and a mean southern displacement vector. The triangulated displacement vector between those two indicates a minor east-west dextral transtension across the Feda-Gertrud Graben boundary faults (Fig. 14). The extension is observable 
Fig. 16. Line drawing and seismic section showing the vertical offset of the Top Chalk reflector accommodated by minor faults cutting the top Chalk reflector (TCH) located above the transition between the Feda Graben and the Gertrud Graben. The box on the line drawing indicates the location of the seismic section. The minor faults and especially the relative subsidence of the TCH in the Feda Graben compared to the Gertrud Graben indicate post-Danian extension across the graben defining fault trend separating the Feda and Gertrud Grabens.
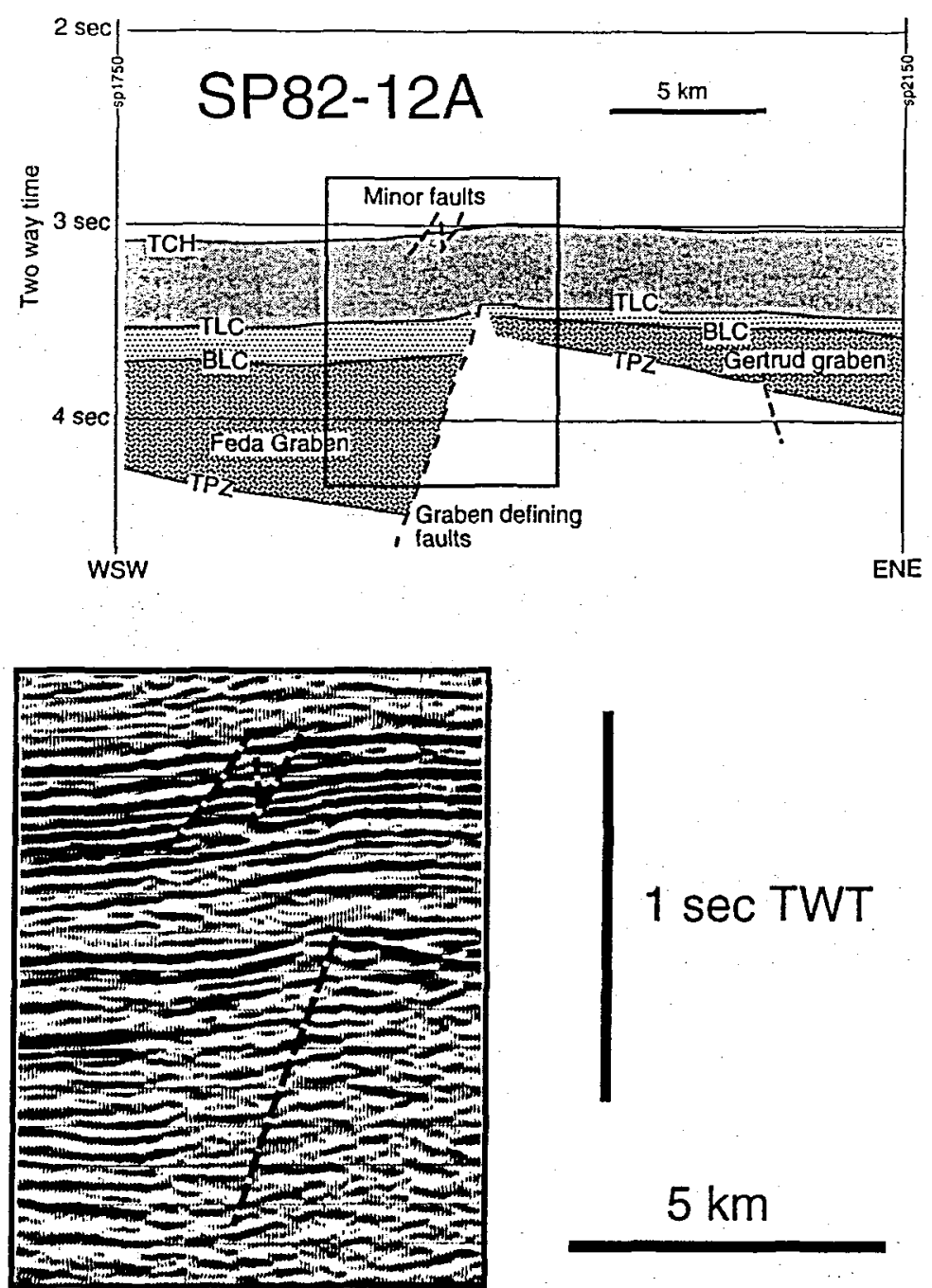

\section{$1 \mathrm{sec}$ TWT}

$5 \mathrm{~km}$ on seismic sections (Fig. 16) as minor normal faults cutting the top Chalk horizon.

The triangulation shows that there is a significant difference in the structural behaviour of the area west of the Arne-Elin trend during the Early and the Late Cretaceous as compared to the deformation across the Arne-Elin trend. The area was characterized by more plastic deformation during the Early Cretaceous, since each graben unit was separated by active normal faults with some strike slip. This is in contrast to the postEarly Cretaceous deformation where most of the faults between the graben units are inactive. The area west of the Arne-Elin trend thus behaved as a rigid body (with the exception of minor faulting between the Feda and Gertrud Grabens).
The presence of salt in the active zones

The block movement causing the inversion (reactivation) of the Arne-Elin trend during the Late Cretaceous/ Paleogene could, from a geometrical point of view, just as well have been accommodated by reactivation of the faults between the Gertrud Graben and Feda Graben. Reactivation (inversion) of the Arne-Elin trend was probably preferred because of the presence of salt underneath faults and fault zones (Fig. 17). Salt may have intruded along the fault plane (perhaps during the earlier period of extension), thereby reducing the friction along the fault plane. At a later episode of transpression the faults may not have had an orientation favorable for reactivation (inversion), but the stress 


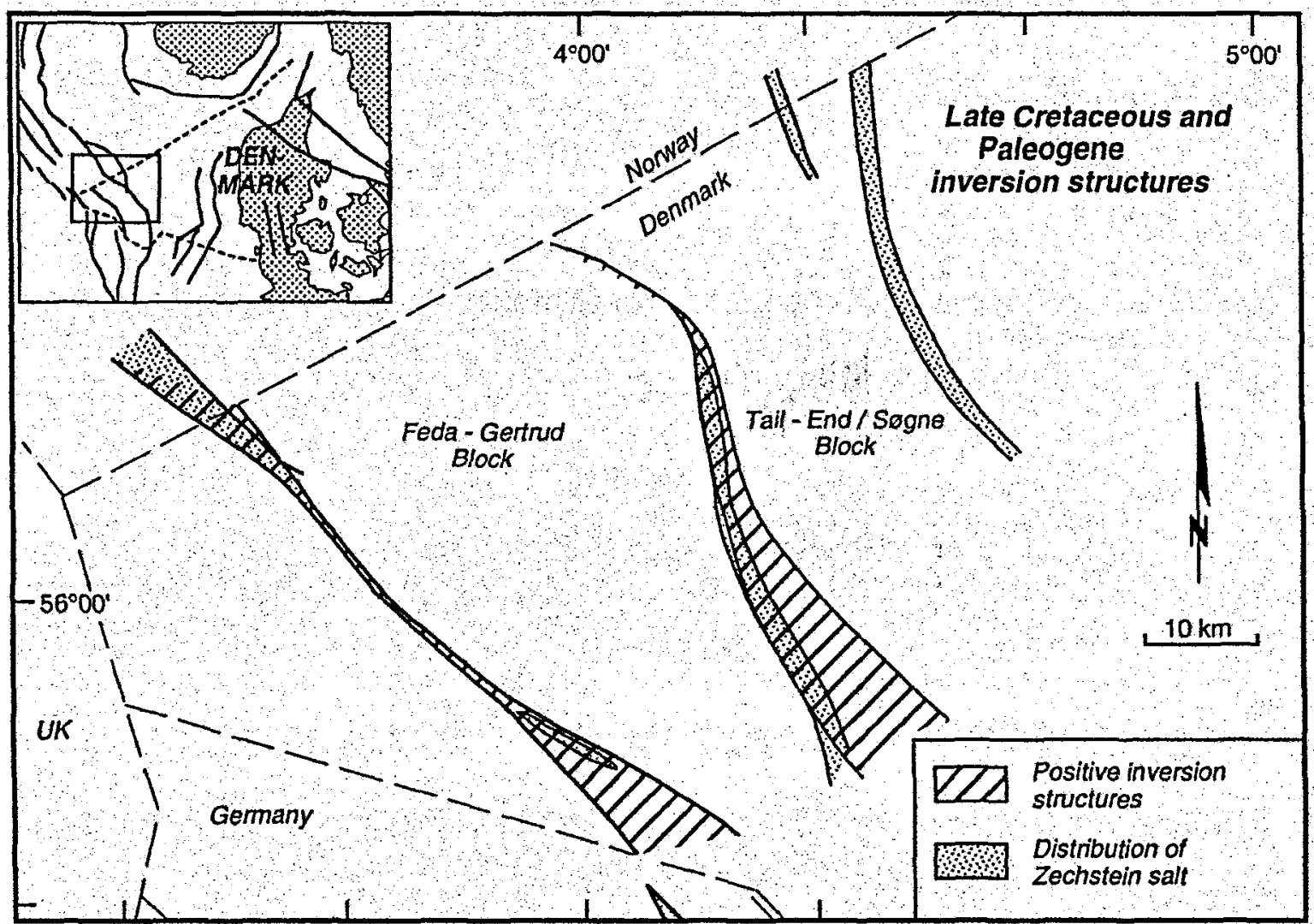

Fig. 17. The map shows the present distribution of Zechstein Salt in the northern part of the Danish Central Graben, and the location of Late Cretaceous/Paleogene positive inversion.

required to reactivate a fault with intruded salt would be much less than the stresses required to generate new faults with a favorable orientation or to invert a fault without salt. The faults separating the Gertrud Graben - Feda Graben are not underlain by salt, and only minor reactivation (normal faulting and thus no inversion) took place during the Late Cretaceous/Paleogene.

\section{Conclusions}

i. The accommodation of strain across a transpressional zone can be unravelled by means of a simple strain analysis, and the size and direction of the relative displacement across the zone can be determined by this method. It is also possible to determine the displacements of the individual phases of movement along a zone where multiple deformation has taken place.

ii. A strain analysis has been performed along the ArneElin trend in the northern part of the Danish Central Graben. The result shows a general sinistral movement with changing transpression and transtension along strike of the zone during the Early
Cretaceous, and a general dextral transpressive movement during the Late Cretaceous/Paleogene.

iii. The strain analysis also gives information about the deformation of the areas adjacent to the transpression zone. Using triangulation it can be shown that movements took place along adjoining fault systems with the same sense of movement as that of the Arne-Elin trend. The triangulation procedure indicates that individual graben units of the Central Graben were deformed internally by movements along minor faults during the Early Cretaceous. In the Late Cretaceous-tertiary the blocks that moved relative to each other were larger and more rigid due to locking of the minor faults separating the blocks at the transition between Early Cretaceous to Late Cretaceous-Paleogene.

iv. The major inversion structures are underlain by Zechstein salt bodies, while synchronous normal faults (local extension) appear to be moving without influence of salt. 


\section{Dansk sammendrag}

I den danske del af Nordsøen findes specielt i Centralgraven en række inversionsstrukturer, der er tolket som resultatet af transpression (d.v.s. sideværts forkastning kombineret med kompression). Artiklen præsenter en metode til bestemmelse af størrelse og orientering af forsætningen på tværs af transpressions og -tensions strukturer. Metoden er anvendt på Arne Elin trendet, en inversionsstruktur beliggende i den nordlige del af Den danske Centralgrav. Områdets forkastninger og topografien af horisonterne er kortlagt på reflektionsseismiske linjer, der ligeledes er anvendt til bestemmelse af strain-værdier.

Resultaterne viser, at der sker en venstrelateral forsætning langs Arne Elin trendet $i$ tidlig Kridt, med en mindre komponent af ekstension, specielt i den sydlige del af det unders $\varnothing$ gte område. I modsætning hertil sker der i sen Kridt og tidlig tertiær en højrelateral forsætning med en komponent af kompression. Resultaterne viser yderligere, at orienteringen af forsætningen (d.v.s. graden af ekstension eller kompression) varierer systematisk langs Arne Elin trendet, og at variationerne kan sammenstilles med reaktivering af strukturelle lineamenter i de tilstødende områder af Central Graven.

\section{References}

Andersen, C., Olsen, J. C., Michelsen, O. \& Nygaard, E. 1982: Structural outline and development. In Michelsen, O. (ed.), Geology of the Danish Central Graben. Danmarks Geologiske Undersøgelse B 8, 9-26.

Blès, J-L. \& Feuga, B. 1986: The fracture of rocks. 130 pp. North Oxford Academic.

Cartwright, J. 1987: Transverse structural zones in continental rifts - an example from the Danish sector of the North Sea. In Brooks, J. \& Glennie, K. W. (ed) Petroleum Geology of North West Europe, 441-453. Graham \& Trotman.

Cartwright, J. A. 1989: The kinematics of inversion in the Danish Central Graben. In: Cooper, M. A. \& Williams, G. D. (ed) Inversion Tectonics. Geological Society Special Publication 44, 153-175.

Emmons, R. C. 1969: Strike-slip rupture patterns in sand models. Tectonophysics 7, 71-87.

Fossen, H. \& Tikoff, B. 1993: The deformation matrix for simultaneous simple shearing, pure shearing and volume change, and its application to transpression-transtension. Journal of Structural Geology 15, 413-422.

Gowers, M. B. \& Sæbøe, A. 1985: On the structural evolution of the Central Trough in the Norwegian and Danish sectors of the North Sea. Marine and Petroleum Geology 2, 298-318.

Harding, T. P. 1983: Graben hydrocarbon plays and structural styles. In Kaasschieter, J. P. H. \& Reijers, A. (ed) Petroleum geology of the southeastern North Sea and the adjacent onshore areas. Geologie en Mijnbouw 62, 3-23.

Harding, T. P. 1985: Seismic Characteristics and Identification of Negative Flower Structures, Positive Flower Struc- tures, and Positive Structural Inversion. American Association of Petroleum Geologists Bulletin 69, 582-600.

Harding, T. P. \& Lowell, J. D. 1979: Structural styles, their plate tectonic habitats, and hydrocarbon traps in petroleum provinces. American Association of Petroleum Geologists Bulletin 63, 1016-1058.

Jones, R. R. \& Tanner, P. W. G. 1995: Strain partitioning in transpression zones. Journal of Structural Geology 17 , 793-802.

Jaeger, J. C. \& Cook, N. G. W. 1969: Fundamentals of Rock Mechanics. 513 pp. London: Methuen \& Co.

Krantz, R. W. 1995: The transpressional strain model applied to strike-slip, oblique-convergent and oblique-divergent deformation. Journal of Structural Geology 17, 1125-1137.

McCoss, A. M. 1986: Simple constructions for deformation in transpression/transtension zones. Journal of Structural Geology 8, 715-718.

Mikkelsen, L. P. 1988: Den strukturelle udvikling i Kridt og Tertiær af den nordvestlige del af dansk sektor, Nordsøen. Unpublished M.Sc. thesis, University of Aarhus, 107 pp.

Mogensen, T. E. 1988: Permo-Jurassisk strukturel udvikling af Central Truget i grænseområdet mellem Danmark og Norge. Unpublished M.Sc. thesis, University of Aarhus, $88 \mathrm{pp}$.

Møller, J. J. 1986: Seismic structural mapping of the Middle and Upper Jurassic in the Danish Central Trough. Danmarks Geologiske Undersøgelse A 13, 37 pp.

Nadai, A. 1950: Theory of flow and fracture of solids. Vol. 1, 572 pp. McGraw-Hill Book Company.

Ramsay, J. G. \& Huber, M. I. 1987: The techniques of modern structural geology. Volume 2: folds and fractures. 700 pp. Academic Press.

Sanderson, D. J. \& Marchini, W. R. D. 1984: Transpression. Journal of Structural Geology 6, 449-458.

Sclater, J. G. \& Christie, P. A. F. 1980: Continental stretching: an explanation of the post-Mid-Cretaceous subsidence of the Central North Sea Basin. Journal of Geophysical Research 85, 3711-3739.

Vejbæk, O. V. 1986: Seismic Stratigraphy and tectonic evolution of the Lower Cretaceous in the Danish Central Trough. Danmarks Geologiske Unders $\emptyset$ gelse A 11, 46 pp.

Vejbæk, O. V. \& Andersen, C. 1987: Cretaceous-Paleogene inversion tectonism in the Danish Central Trough. Tectonophysics $137,221-238$.

Ziegler, P. A. 1989: Geodynamic model for Alpine intraplate compressional deformation in Western and Central Europe. In Cooper, M. A. \& Williams, G. D. (ed) Inversion Tectonics. Geological Society Special Publication $44,63-87$. 